\title{
Effectiveness Of Seesaw As A Digital Learning Innovation To Improve Student Information Literacy
}

\author{
Uswatun Hasanah 1), Zulela, M.S. ${ }^{2)}$, Edwita ${ }^{3)}$, Ahmad Januar 4), Agung Perdana ${ }^{5)}$ \\ 1,2,3 Universitas Negeri Jakarta \\ ${ }^{3}$ SDN Cipulir 11 Pagi, Jakarta \\ ${ }^{4}$ SMPN 105 Jakarta
}

Corresponding author email: uswatunhasanah@unj.ac.id

\begin{tabular}{ll}
\hline & \multicolumn{1}{c}{ Abstract } \\
\hline Kata Kunci: & This study aims to analyze the effectiveness of seesaw as a digital learning \\
Digital Learning, & innovation to improve student information literacy. This type of research \\
Literacy & method used is a quantitative method with a quasi-experimental design and \\
& uses a one-group pretest-posttest with control group design. The sample used \\
& was 100 second semester students of Elementary School Teacher Education, \\
& Jakarta State University selected with technique a probability sample. The \\
& results of this study prove that the use of-based digital learning seesaw \\
& obtained significant values so that it is effectively used in improving student \\
& information literacy. This digital learning design requires students to be \\
& selective in analyzing and evaluating information generated from different \\
& sources. This research can be used as input for education practitioners, \\
& especially lecturers in developing learning that adapts to the needs of the \\
& times and still requires students to have information literacy.
\end{tabular}

@Inventa:Jurnal Pendidikan Sekolah Dasar Copy Right

\section{Introduction}

The 4.0 industrial revolution was marked by the presence of four things, namely supercomputers, artificial intelligence, cyber systems, and manufacturing collaboration. Therefore, competence is needed that is able to balance the presence of these four things in the era of Education 4.0. The competencies that must be possessed in the 21 st Century are known as 4C (Communication, Collaboration, Critical Thinking and Problem Solving, and Creativity and Innovation) (Widana, 2017).
These four competencies are the real abilities to be aimed at with the IQF Curriculum.

Ease of access in finding information via the internet has positive and negative impacts among students. They can actively search for sources of information relevant to their assignments. However, the amount of information obtained makes them less selective in choosing the sources used. Based on the (WSIS) Declaration which states that everyone can create, access, use and share or share information and knowledge, with the consequence that 
everyone must be able to face and master information properly (Julien, 2016).

However, most students still use information that cannot be accounted for, such as not including a clear source of information for assignment references. This is based on observations on the second semester students of Elementary School Teacher Education, Jakarta State University. The existence of such problems shows that the ability to process information is very important for students to have. In this case it is said information literacy. Among students, information literacy is very active role in the continuity of lectures where the tasks and activities always refer to the internet / digital sources. Students must have the ability to access, analyze, evaluate and communicate information in various forms of printed and non-printed messages. Information literacy also involves a person's awareness of the level of information literacy and the development of information literacy in him. Information literacy is the ability to know when there is a need for information, to be able to identify, find, evaluate, and effectively use that information for the issues or problems encountered.

According to the American Library Association (ALA), information literacy is a set of abilities that one needs to realize when information is needed and the ability to place, evaluate \& use information needed effectively (Holliday et al., 2015).
Information Literacy is the main key in increasing student knowledge (Thammasaeng et al., 2016). With this information literacy students will be able to learn independently, because it involves recognizing when information is needed and being able to efficiently search, accurately evaluate, effectively use, and clearly communicate.

The Ministry of Education and Culture has a National Literacy Movement (GLN) program number 23 of 2015 concerning the Development of Characteristics (Nasrullah Rullie, 2017). One form of literacy that is integrated in learning content is information literacy. This literacy is an ability to process information that comes from digital sources. People who have information literacy can not only read digital information but can analyze the truth of information from digital sources (Masitoh, 2018).

The Standing Conference of the National and University Libraries (McGuinness, 1999) released a model of information literacy known as "the Seven Headline Skills" describing that information literacy in tertiary institutions includes:

Table 1. The Seven Headline Skills

1 The ability to recognize the information needed

2. The ability to analyze the right types of sources, both printed and non-printed and select the right sources for the problem being handled

3. Ability to build strategies for finding 
information

4. The ability to find and access information with the right search techniques

5. Ability to compare and evaluate information generated from different sources

6. The ability to organize, use and communicate information to others in an appropriate way according to conditions

7. The ability to combine and build on existing information to create new knowledge

Based on the table above it can be assumed that an information literate can not only process information but can also create, collaborate, communicate, and work according to ethical rules, and understand when and how technology must be used to be effective in achieving goals. The development of this digital age also influenced the characteristics of learning among students. Meaningful learning should be able to facilitate them to adapt to the times (Fahrurrozi et al., 2019; Rosmiati et al., 2016). Seesaw application can be a learning innovation today. In-based learning seesaw, lecturers and students will be digitally connected (Tecce DeCarlo et al., 2018). Through-based learning seesaw, lecturers and students can carry out learning effectively because both lecturers and students can collect assignments, distribute assignments, and assess assignments without being bound by the lesson time limit. In addition-based seesaw learning is environmentally friendly learning because in its implementation it minimizes the use of paper (paperless) (Mustaniroh, 2015).

Seeing the need for a learning that can adapt the development of the times, researchers are interested in developing abased learning design seesaw to improve student information literacy. Preliminary studies conducted by researchers depart from research that discusses the importance of information literacy for a student. This literacy becomes important where one is able to process information that comes from digital sources (Kurnia \& Astuti, 2017; Silvana \& Darmawan, nd; Stefany et al., 2018).

Several previous studies that have discussed the role of information literacy include (A'yuni, 2015; Akbar \& Anggaraeni, 2017; Alexander et al., 2016; Bhatt \& MacKenzie, 2019; Buckingham, 2008; Chan et al., 2017; Fahrurrozi et al., 2019; Jan, 2018; Kirchoff, 2017; Kurnia Sholihah, 2016; Nurjanah et al., 2019; Rohmadi \& Hum, 2018; Saliyeva et al., 2016; Son \& Park, 2017; Tecce DeCarlo et al. , 2018; Traxler, 2018; West, 2019; Zwart et al., 2017). The results of the above study indicate that information literacy is an important thing that must be mastered by students and can be improved by a digital learning model. Theapplication seesaw can be used as an innovation in contemporary learning-based Seesaw Learning has greatly contributed to learning in the 21 st century. 
The novelty in this research is information literacy that will be measured is information literacy among "students" through-based learning design seesaw that will be applied to BASKOMI learning courses namely Language as a Scientific Communicating Facility. This research can be used as an innovation in 21 st century learning among students. In addition, this research also supports the government in minimizing the use of paper (paperless).

\section{Method}

\section{Research Design}

This study aims to analyze the effectiveness of Seesaw as a digital learning innovation to improve student information literacy. The type of method used is a quantitative method with a quasiexperimental method and uses a one-group pretest-posttest with control group design, that is, a research design that exists pretest before being treated and posttest after treated (Creswell, 2008). This it can be known more accurately, because it can compare before and after being given treatment. The implementation of the one group pretestposttest with control group design was carried out twice, namely before the experiment (O1) was called a pretest, and after the experiment $(\mathrm{O} 2)$ was called the posttest, while the constellation can be seen in the following table:
Table 2. Constellation of One Group PretestPosttest With Control Group Design

\begin{tabular}{ccc}
\hline Pretest & Treatment & Posttest \\
\hline O1 & $\mathrm{X}$ & $\mathrm{O} 2$ \\
\hline
\end{tabular}

\section{Respondent}

Respondents in this study were second semester students who took Language course as a Scientific Communication Facility (BASKOMI). The study was conducted at the Primary School Teacher Education campus, Jakarta State University. The number of respondents in this study were 100 students with different characteristics. The selection of respondents using a probability sampling technique is a technique that takes samples that provide equal opportunities for any non-members. The advantage of the probability method is that it can calculate sampling errors from the results of data to be obtained from respondents, whereas in the non-probability method of sampling errors from the population it cannot be obtained from respondents (Gall et al., 1996).

\section{Instrument}

This research instrument uses tests as a reference to measure student information literacy. The instruments used by researchers include information literacy indicators that have been developed by the Standing Conference of National and University Libraries (McGuinness, 1999). 


\section{Data Analysis Technique}

The data analysis technique in this research is by analyzing the data then drawing conclusions using statistical parameters. Hypothesis testing uses the $\mathrm{t}$ Paired Samples Test with the help of the SPSS 24 program, which compares the mean between Pretest and Posttest. If the value of $t$ count is smaller than $\mathrm{t}$ table, then $\mathrm{Ha}$ is rejected, if $\mathrm{t}$ count is greater than $\mathrm{t}$ table then Ha is accepted.

\section{Results}

The results of this study statistically explain the effectiveness of Seesaw as a digital learning innovation to improve student information literacy. The research results can be seen in the following explanation:

Table 4. Descriptive Statistics

\begin{tabular}{|c|c|c|c|}
\hline & & Pretest & Posttest \\
\hline \multirow[t]{2}{*}{$\mathrm{N}$} & Valid & 100 & 98 \\
\hline & $\begin{array}{l}\text { Missin } \\
\mathrm{g}\end{array}$ & 0 & 2 \\
\hline \multicolumn{2}{|c|}{ Mean } & 69.54 & 80.92 \\
\hline \multicolumn{2}{|c|}{$\begin{array}{l}\text { Std. Error of } \\
\text { Mean }\end{array}$} & .392 & .684 \\
\hline \multicolumn{2}{|c|}{ Median } & 70.00 & 80.00 \\
\hline \multicolumn{2}{|c|}{ Mode } & 70 & 77 \\
\hline \multicolumn{2}{|c|}{ Std. Deviation } & 3.507 & 6.038 \\
\hline \multicolumn{2}{|c|}{ Variance } & 12.302 & 36.462 \\
\hline \multicolumn{2}{|c|}{ Range } & 12 & 20 \\
\hline \multicolumn{2}{|c|}{ Minimum } & 65 & 70 \\
\hline \multicolumn{2}{|c|}{ Maximum } & 77 & 90 \\
\hline \multicolumn{2}{|c|}{ Sum } & 5563 & 6312 \\
\hline
\end{tabular}

Table 3. Paired Samples Statistics

\begin{tabular}{|l|c|r|r|c|}
\hline & Mean & \multicolumn{1}{c|}{ N } & $\begin{array}{c}\text { Std. } \\
\text { Deviation }\end{array}$ & $\begin{array}{c}\text { Std. Error } \\
\text { Mean }\end{array}$ \\
\hline Pretest & 69.58 & 100 & 3.529 & .400 \\
\hline Posttest & 80.92 & 98 & 6.038 & .684 \\
\hline
\end{tabular}

Based on the table above, the results pretest show a mean value of 69,54 , a median value obtained of 70.00 std value, a deviation obtained of 3,507 , a variance value obtained of 12,302, a minimum value

Table 5. Paired Samples Test

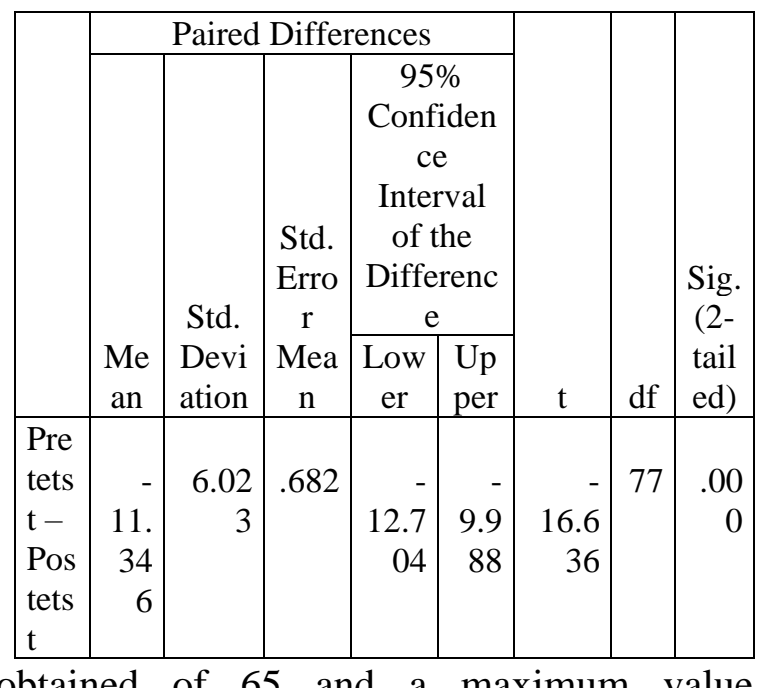

obtained of 65 and a maximum value obtained of 77 . Furthermore on the part posttest obtained a mean value of 80.92 , a median value obtained at 80.00 std value, a deviation was obtained at 6038, a variance value obtained at 36,462 , a minimum value obtained at 80 , a maximum value obtained at 90. Then tested paired samples statistics were for distinguish the comparison between before and after being given a-based digital learning treatment seesaw can be seen in the output table below: 
In the paired samples statistics table above, the value pretest is the value before using the application seesaw to get the mean $=69,58$ while the posttest value is the value after using the application seesaw to get the mean $=80.92$. This can be interpreted that there is a significant comparison between scores pretest and posttest in Seesaw as digital learning innovations to improve student information literacy on students' narrative writing skills in elementary school. The following can be seen the comparison between the pretest and posttest in the table and graph below:

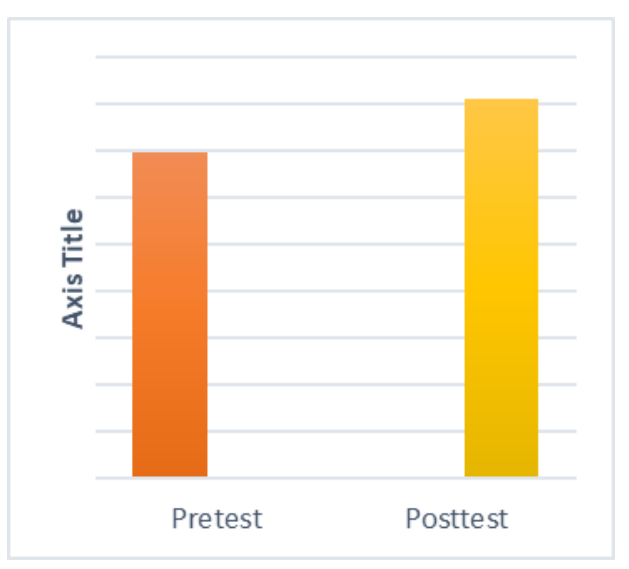

Figure 1. Comparison of pretest and posttest and table include:

Table 6. Paired Samples Correlation:

\begin{tabular}{lrrr}
\hline & N & Correlation & \multicolumn{1}{c}{ Sig. } \\
\hline $\begin{array}{l}\text { Pretest \& } \\
\text { Posttest }\end{array}$ & 98 & .296 & .008 \\
\hline
\end{tabular}

In the table Paired Samples Correlations above obtained a correlation coefficient of 29.6 with a sig number, or pvalue $=0.08 \geq 0.05$ can be interpreted that Seesaw as a digital learning innovation has significant value. Furthermore, to find out the value of Paired Samples Test can be seen in the following table:

In the table Paired Samples Test above obtained a mean difference $=-11,346$ which means the student's information literacy score after being given digital learning treatment with application seesaw is higher than before being given treatment. Furthermore, in this table also obtained the mean error standard which shows the standard error rate of the average difference. Furthermore, the most important results from this table are the statistical price $\mathrm{t}=-16.636$ with $\mathrm{df} 77$ and the significant value or $\mathrm{p}$-value $0.000<0.05$ or HO is rejected. Thus it can be concluded that there differences in results are significant between student information literacy scores before and after treatment is given.

\section{Discussion}

Based on the findings in the study stated that information literacy can be improved through digital learning. The results of this study are relevant to research conducted by (Doyle et al., 2019; Durodolu \& Mojapelo, 2020; Gu, 2020) where digital learning models can have a positive impact on students in developing information literacy. In this case digital learning is carried out using the application seesaw. This application is very easy for lecturers and students in online lecture activities such as discussion related to the material, task collection, task analysis to authentic assessment. 
After being treated with-based digital learning seesaw, students become trained in accessing tasks digitally. They also become disciplined and responsible in quoting material available on the internet. Basically the ability of information literacy does not come just like that but it is obtained through the learning process in a training or formal education. Information literacy learning taught refers to the literacy model developed by Michael B. Eisenberg and Robert E. Berkowitz in 1987 which consists of six skills with 12 steps (Cowan et al., 2016).

Information literacy is needed to improve the quality of self within the framework of lifelong learning (Nurhayati, 2019). When someone intends to improve his standard of living, then he needs something more than himself, namely selfdevelopment, better skills, education or better performance. A Person is said to have information literacy if he has the ability to recognize information, analyze the right types of sources, both print and non-print and select the right sources for the problem being addressed. This is very relevant to learning objectives that are designed based on the application seesaw.

In the-based learning design seesaw developed by researchers there are several materials and projects that students must master. In the final project of the Baskomi course, students are asked to develop scientific essays based on valid data and references. In addition, in developing this scientific essay, students are also required to write it in a systematic arrangement based on correct spelling rules and proper scientific notation. Of course, the existence of this assignment requires students to access some references that are relevant to their assignments and include the source of references in the assignment. Thus, this activity will train students in comparing and evaluating information generated from different sources.

In addition, -based digital learning seesaw this is a learning platform that allows each student to have a collaborative learning journal, with the option to share content with other students in the class by lecturers (Putri, Dhia GR, 2017). In fact, lecturers can also directly share texts, images, videos, images and links that students can see on their android / mobile phone, using applications for iPhone, iPad and android devices. The 21 st century is characterized by the digital era (Njenga, 2018). Teaching material is digitally designed and requires students to be active in accessing and combining information with appropriate search techniques and building on existing information to be able to create new knowledge. Of course this activity can increase the literacy of the information it has. In addition, the discussion feature in the application seesaw helps students organize, use and communicate information 
to others in a way that is appropriate to the conditions. Thus seesaw can be used as a digital learning innovation to improve information literacy in students.

\section{Conclusion}

Based on the research findings said that seesaw can be used as a digital learning innovation to improve student information literacy. This matter has been proven that score of student information literacy after given based learning treatment seesaw is higher than student information literacy score before being given treatment.

This research can be used as input for education practitioners, especially lecturers in developing learning that adapts to the needs of the times and still requires students to have information literacy. This literacy is important so that the next generation of the nation, especially students as agents of change can be selective in creating, accessing, using and sharing or sharing information and knowledge with others.

In addition, this research also supports government programs in implementing cutting-edge technology-based learning and environmentally friendly because it reduces the use of paper (paperless).

\section{References}

A'yuni, Q. Q. (2015). Literasi Digital Remaha di Kota Surabaya (Studi Deskriptif tentang Tingkat Kompetensi Literasi Digital pada Remaja SMP, SMA dan Mahasiswa di Kota Surabaya). Libri-Net, 4(2), 1-15. http://journal.unair.ac.id/LN@literasi- digital-remaja-di-kota-surabaya-article-

9195-media-136-category-8.html

Akbar, M. F., \& Anggaraeni, F. D. (2017). Technology in Education: Digital Literation and Self-Directed Learning in Students Students. Jurnal Indigenous, 2(1), 28-38.

Alexander, B., Adams Becker, S., \& Cummins, M. (2016). An NMC Horizon Project Strategic Brief. 3(October). http://cdn.nmc.org/media/2016-nmchorizon-strategic-brief-digitalliteracy.pdf

Bhatt, I., \& MacKenzie, A. (2019). Just Google it! Digital literacy and the epistemology of ignorance. Teaching in Higher Education, 24(3), 302-317. https://doi.org/10.1080/13562517.2018. 1547276

Buckingham, D. (2008). Defining Digital Literacy: What Do Young People Need to Know. Digital Literacies: Concepts, Policies and Practices, 73-89.

Chan, B. S. K., Churchill, D., \& Chiu, T. K. F. (2017). Digital Literacy Learning In Higher Education Through Digital Storytelling Approach. Journal of International Education Research (JIER), 13(1), 1. https://doi.org/10.19030/jier.v13i1.9907

Cowan, E., Cowan, S., \& Eva, C. \&. (2016). Changing Our Aim. Communications in Information Literacy |, 10(2), 163-177.

Creswell, J. W. (2008). Educational Research: Planning, Conducting, and Evaluating Quantitative and Qualitative Reseach. Pearson.

Doyle, M., Foster, B., \& YukhymenkoLescroart, M. A. (2019). Initial development of the perception of information literacy scale (PILS). Communications in Information Literacy, 13(2), 205-227. https://doi.org/10.15760/comminfolit.20 19.13.2.5

Durodolu, O. O., \& Mojapelo, S. M. (2020). Contextualisation of the information 
literacy environment in the South African education sector. Electronic Journal of E-Learning, 18(1), 57-68. https://doi.org/10.34190/EJEL.20.18.1.0 05

Fahrurrozi, Hasanah, U., \& Dewi, R. S. (2019). Integrated Learning Design Based on Google Classroom to Improve Student Digital Literacy. 2019 5th International Conference on Education and Technology, ICET 2019, 108-111. https://doi.org/10.1109/ICET48172.201 9.8987219

Gall, M. D., Borg, W. R., \& Gall, J. P. (1996). Educational research: An introduction, 6th ed. In Educational research: An introduction, 6th ed.

$\mathrm{Gu}$, Y. (2020). Enhancement of College English Teachers' Information Literacy in Information Environment. International Education Studies, 13(4), 106.

https://doi.org/10.5539/ies.v13n4p106

Holliday, W., Dance, B., Davis, E., Hedrich, A., \& Lundstrom, K. (2015). An Information Literacy Snapshot: Authentic Assessment across the Curriculum.

https://doi.org/10.5860/crl.76.2.170

Jan, S. (2018). Investigating the relationship between students' digital literacy and their attitude towards using ICT. 2017.

Julien, H. (2016). Beyond the hyperbole: Information literacy reconsidered. Communications in Information Literacy, 10(2), 124-131. https://doi.org/10.15760/comminfolit.20 16.10.2.28

Kirchoff, J. (2017). Using Digital Comics to Develop Digital Literacy: Fostering Functionally, Critically, and Rhetorically Literate Students. Texas Journal of Literacy Education, 5(2), 117-129.

http://ezproxy.lib.uconn.edu/login?url=h ttps://search.ebscohost.com/login.aspx? direct $=$ true $\& \mathrm{db}=$ eric $\& A N=\mathrm{EJ} 1162692 \&$ site $=$ ehost-live
Kurnia, N., \& Astuti, S. I. (2017). Peta gerakan literasi digital di indonesia. Informasi: Kajian Ilmu Komunikasi, 47(2), 149-166.

Kurnia Sholihah, S. H. (2016). Analisis Literasi Digital: Studi Pemanfaatan Jurnal Elektronik Oleh Mahasiswa Magister Manajemen Di Perpustakaan Uksw Salatiga. IOSR Journal of Economics and Finance, 3(1), 56. https://doi.org/https://doi.org/10.3929/et hz-b-000238666

Masitoh, S. (2018). Blended Learning Berwawasan Literasi Digital Suatu Upaya Meningkatkan Kualitas Pembelajaran dan Membangun Generasi Emas 2045. Proceedings of the ICECRS, 1(3), 13-34. https://doi.org/10.21070/picecrs.v1i3.13 77

McGuinness, C. (1999). Information skills in higher education. British Dental Journal, 189(3),

262-281. https://doi.org/10.1108/0001253091095 9817

Mustaniroh, S. A. (2015). Penerapan Google Classroom Sebagai Media Pembelajaran Pada Pelajaran Kimia di SMK Negeri 2 Temanggung.

Nasrullah Rullie. (2017). Materi Pendukung Literasi Digital.

Njenga, J. K. (2018). Digital literacy: The quest of an inclusive definition. Reading \& Writing, 9(1), 1-7. https://doi.org/10.4102/rw.v9i1.183

Nurjanah, E., Rusmana, A., \& Yanto, A. (2019). Hubungan Literasi Digital dengan Kualitas Penggunaan EResources. Lentera Pustaka: Jurnal Kajian Ilmu Perpustakaan, Informasi Dan Kearsipan, 3(2), 117. https://doi.org/10.14710/lenpust.v3i2.16 737

Putri, Dhia G.R, C. B. (2017). Communication Effectiveness of Online Media Google. 4(01), 1-15. 
Rohmadi, M., \& Hum, M. (2018). Literasi digital. 20-23.

Rosmiati, R., Mahmud, A., \& Talib, S. B. (2016). The effectiveness of learning model of basic education with characterbased at universitas muslim Indonesia. International Journal of Environmental and Science Education, 11(12), 56335643.

Saliyeva, A. Z., Zhumabekova, F. N., Kashkynbay, B. B., Saurbekova, G., Tauasarova, D., Toktarbaev, D., \& Sakenov, J. (2016). On the students' ability to use digital educational resources. International Journal of Environmental and Science Education, 11(11), 4669-4679.

Silvana, H., \& Darmawan, C. (n.d.). Pendidikan Literasi Digital Di Kalangan Usia Muda Di Kota Bandung. 154-167.

Son, J.-B., \& Park, M. (2017). Digital literacy of language learners in two different contexts sang-soon Park. 13(2), 1832-4215.

Stefany, S., . N., \& . B. (2018). Literasi Digital Dan Pembukaan Diri: Studi Korelasi Penggunaan Media Sosial Pada Pelajar Remaja di Kota Medan. Sosioglobal: Jurnal Pemikiran Dan Penelitian Sosiologi, 2(1), 10-31. https://doi.org/10.24198/jsg.v2i1.15268

Tecce DeCarlo, M. J., Grant, A., Lee, V. J., \& Neuman, D. (2018). Information and Digital Literacies in a Kindergarten Classroom: An I-LEARN Case Study. Early Childhood Education Journal, 46(3), 265-275. https://doi.org/10.1007/s10643-0170857-7

Thammasaeng, P., Pupat, P., \& Petchaboon, S. (2016). Needs assessment of information and communication technology literacy (ICT literacy) of students in secondary educational service area. International Journal of Emerging Technologies in Learning, 11(12), 9-13. https://doi.org/10.3991/ijet.v11i12.5798
Traxler, J. (2018). Digital literacy: A palestinian refugee perspective. Research in Learning Technology, 26(1063519), 1-21. https://doi.org/10.25304/rlt.v26.1983

West, J. A. (2019). Using new literacies theory as a lens for analyzing technology-mediated literacy classrooms. E-Learning and Digital Media, 16(2), 151-173. https://doi.org/10.1177/2042753019828 355

Widana, I. W. (2017). Higher Order Thinking Skills Assessment (HOTS) I Wayan Widana. 3(1), 32-44.

Zwart, D. P., Van Luit, J. E. H., Noroozi, O., \& Goei, S. L. (2017). The effects of digital learning material on students' mathematics learning in vocational education. Cogent Education, 4(1), 110.

https://doi.org/10.1080/2331186X.2017. 1313581 